\title{
To Save Or To Spend: That Is The Tax Question?
}

Tricia Snyder, (Email: Snydert@wpunj.edu), William Paterson University

\begin{abstract}
While the effects of interest rates on consumption and savings has always been a concern to economists, there is still a great debate regarding the magnitude of the after-tax interest rate effect on savings. The response of consumption and savings to such changes in after tax interest rates potentially alter the United States private savings rate, which may influence our economic growth. While the Federal Reserve has executed the most aggressive expansionary monetary policy in history by lowering the Federal Funds interest rate by more than 10 times in the past year in an attempt to increase consumption to rebound from the current recession, this may ultimately reduce savings. If savings fall, it potentially reduces our ability to spend in the future? In Solow's Growth model, the biggest determinant of future growth in an economy is the savings rate. The current savings rate in the US is at an all time low and is much lower than that of other nations, such as Germany and Japan. So, how can policy makers increase savings in the US? Can the U.S. increase savings by lowering the capital gains tax rate, which changes the after tax return on capital investment? If so, how effective will President Bush's proposed capital gains tax cut be on altering our savings rate? To better understand after-tax interest rate effects on savings, one needs to discover the interest elasticity of savings to different types of taxes, such as capital gains and consumption taxes. If the private savings rate is sensitive to the after-tax interest rate return, then a capital gains tax, income tax, and sales tax will have very different effects on savings. The more sensitive the savings rate is to the after tax interest rate, the more an increase in the after tax interest rate will cause an increase in savings. To assess the current interest elasticity of consumption/savings on the after tax real return of interest, I build on Boskin's (1978) model with a simultaneous equations model and more recent data. Specifically, I estimate the log of consumption on wealth, unemployment, interest rates, and disposable private income, and the after tax return of the Moody's AAA Bond Rate. To avoid the potential endogeneity bias between these variables, I use a simultaneous equation approach. Results will help determine if the U.S. can increase its savings by lowering the tax rates on investment. In general, this paper finds that the elasticity of substitution is close to .2, which suggests that the elasticity of substitution is quite small and stable. As Feldstein suggests this shows that a reduction in an income or sales tax will generate greater savings than a reduction in the capital gains income tax.
\end{abstract}

\subsection{Introduction}

W

hile the effects of interest rates on consumption and savings has always been a concern to economists, there is still a great debate regarding the magnitude of the after-tax interest rate effect on savings. The response of consumption and savings to changes in after tax interest rates potentially alters the United States private savings rate, which may influence our economic growth. While the Federal Reserve has executed the most aggressive expansionary monetary policy in history by lowering the Federal Funds interest rate by more than 10 times in the past year in an attempt to increase consumption to rebound from the current recession, however, this ultimately reduces savings.

Readers with comments or questions are encouraged to contact the author via email. 
If we reduce savings, will this potentially reduce our ability to spend in the future? Solow's Growth model shows that the biggest determinant of future growth in an economy is savings. The current savings rate in the US is at an all time low and is much lower than that of other nations, such as Germany and Japan. Browne and Hellerstein (1997) show that while Japan has had a very high savings rate relative to the United States, until recently they have also had very strong economic growth. They go on to state that the decline in savings has been particularly pronounced since the early 1980s. This decline in savings is problematic because it implies a decline in investment, which is often seen as the key to productivity growth.

So, how can policy makers increase savings in the US? Can the U.S. increase savings by lowering the capital gains tax rates and changing the after tax return on capital investment? How effective will President Bush's proposed capital gains tax cut be on altering our savings rate? To better understand after-tax interest rate effects on savings and growth, one needs to discover the interest elasticity of savings. If the private savings rate is sensitive to the after-tax interest rate return then an income tax and a consumption tax will have very different effects on savings. The more sensitive the savings rate is to after tax interest rate returns the more an increase in the after tax interest rate will cause an increase in savings. Even Keynes assumes that interest rates equate savings and investment.

Assuming the elasticity of substitution is relatively large, an increase in savings potentially increases investment and Solow's capital to labor ratio. According to Solow's growth theory, the increase in capital to labor increases the marginal productivity of labor, which increases the real wage. An increase in the savings rate will indirectly raise the wage rate in the long run, while the wage rate will be lower due to the relative increase in the return to capital in the short-run. If the elasticity of savings is relatively small and stable, then an increase in the after-tax interest rate generates only a small and minimal effect on savings, creating very little change in the capital to labor ratio and ultimately the productivity of labor.

To assess the current interest elasticity of consumption/savings on the after tax real return of interest, I build on Boskin's (1978) model with a simultaneous equations model and more recent data. Specifically, I estimate the $\log$ of consumption on wealth, unemployment, interest rates, and disposable private income, and the after tax return of the Moody's AAA Bond Rate. To avoid the potential endogeneity bias between these variables, I use a simultaneous equation approach. Results will help determine if the U.S. can increase its savings by lowering the tax rates on investment.

\subsection{Literature Review}

While several economists have tried to estimate the elasticity of the savings rate to the after-tax real interest rate, they have found a wide array of results. Prior to Michael Boskin (1978), most estimates of the interest elasticity of savings where extremely low. In fact, Pechman (1971) along with Dension's Law suggested that the savings rate is constant and unaffected by changes in the real after tax interest rate. Therefore, they contend that changes in income and capital gains tax rates have little to no effect on savings and future growth, thus causing no change in the longrun productivity of labor.

Boskin's (1978) and Summers (1981) were among the first to find a high interest rate elasticity of savings, supporting the importance of interest rates in the savings decision. Using a variety of estimation techniques, Boskin shows that private savings are strongly affected by changes in the real after tax rate of return. Boskin's regresses the $\log$ of consumption on the U.S. income (measured as GDP), last years income, wealth, unemployment and the nominal long-term interest rate or

$$
\ln C=\beta_{0}+\beta_{1} \ln D P I_{t}+\beta_{2} \ln D P I_{t-1}+\beta_{3} \ln \Omega_{t-1}-\beta_{4} \ln U_{t}-\beta_{5} R_{t}
$$

where $C$ represents consumption, DPI represents disposable private income, $\Omega$ represents wealth measured as the market value of private nonhuman assets, $R$ represents the nominal after tax rates of return for Moody's AAA bond rate adjusted for the average marginal tax rate on interest income, $t$ represents time, and $\beta$ represents the coefficients. 
He then adds production and estimates the elasticity of substitution written as:

$\ln \left(\frac{\mathrm{wL}}{\mathrm{y}}\right)=\partial_{1}+\beta_{1} \ln (\mathrm{w})+\beta_{2} t$

where $w$ represents the wage rate, $L$ represent labor supply, and $y$ is production.

After estimating the elasticity of savings, Boskin finds that it averages close to .44 in his estimates. Although this does not appear high, it is much higher than the previous .2 that earlier researchers found. Due to the high value of the elasticity of savings with respect to interest rates, Boskin argues that an income tax decreases the after tax return, reducing savings which causes a reduction in the capital to labor ratio, ultimately lowering productivity and the wage rate. Boskin suggests that the reduction in the real net rate of return will generate a welfare loss that exceeds $\$ 50$ billion in 1978 dollars. He also estimates that the redistribution of income from labor to capital exceeds one-seventh of capital's share of gross income. Summers (1981) supports Boskin's results, suggesting that a shift away from a capital income tax would increase capital investment by $18 \%$ and consumption by close to $16 \%$. Summers finds a high elasticity of savings, suggesting that the long-run gain could exceed $\$ 150$ billion annually. ${ }^{1}$

Incorporating inflation into the model, Bruce and Mintz (1984) and Klempere and O'Neil (1987) find that permanent changes in the rate of inflation alter the real stock of capital. While inflation reduces the demand for money causing an indirect decline in the real return to capital, it also reduces the real after tax return of capital. Combined these two forces create a reallocation of capital and lower the steady state, which increases the interest rate elasticity of savings, supporting the earlier findings of Boskin.

Seidman and Maurer (1982) show that a tax conversion away from a capital income tax shifts disposable income from low too high savers increasing the capital intensity, regardless of the elasticity of savings. ${ }^{2}$ Therefore, an income tax, as opposed to a capital gains tax, will lower the steady state level of capital shifting income away from the higher capital earners to the lower capital earners. The decline in savings by high capital income earners is greater than the savings of the low-income earners, collectively lowering total savings.

\subsection{Alternative view}

Feldstein (1978) and Evans (1983) present contradictory results. Evans finds that the elasticity of saving is very small. Similarly, Feldstein uses a two-period model and shows that an increase in the net rate of return will not increase savings due to the income and substitution effect working in opposite directions. The substitution effect of consumption taxes on capital income is negative, reducing savings. If the elasticity of substitution is less than one, future consumption will increase while current savings decrease.

Feldstein suggests that a consumption tax will tax young individuals, permitting them to save less in early years and consume more in later years. An increase in the net rate of interest will lower the price of retirement consumption, causing savings to fall while consumption increases. Assuming a constant pattern of government spending, an increase in government savings outweighs a decrease in private savings, causing national savings (private and public savings) to increase when a labor income tax or consumption tax are levied in lieu of a capital gains tax. The removal of a capital income tax omits the first generation of retirees from the tax burden, causing the total value of all tax receipts to decline, which lowers government savings and national savings.

Kotlikoff and Summers (1979) also do not favor a capital gains tax cut instead of an income tax cut. They show that increasing the increasing the interest rate income tax will make leisure less attractive and increase human capital accumulation. Therefore, consumption in both periods will increase lowering savings. They show that unlike

\footnotetext{
${ }^{1}$ Summers uses a muti-period general equilibrium model with the economy not starting at Solow's Golden rule level (or optimal level of capital).

${ }^{2}$ Seidman and Maurer (1982) allow for different marginal propensities to save between high and low income earners.
} 
an income tax increase, a capital gains tax effects the elasticity of human capital, therefore, capital and the capital to labor ratio, does not endure the brunt of an capital gain tax even in the long run.

According to Uhlig and Yanagawa (1996) and Sandmo (1981), the sign of the substitution effect is ambiguous and depends on which constraint is used. The compensated elasticity of savings with respect to price is negative if and only if the elasticity of demand for retirement consumption is less than one. While the substitution effect of a price increase on consumption is always negative, what happens to savings depends on the sign and magnitude of the compensated interest effect on consumption. Assuming endogenous growth, Uhlig and Yanagawa find that increasing capital income taxes leads to faster growth in overlapping generations due to capital income accruing to the elderly. Taxing capital gains income relieves the tax burden on the young, leaving them with more income to save. Assuming the interest elasticity of savings is low the net effect on savings is positive. They show a strong correlation between increases in the capital gains income tax rate and the savings rate, suggesting that a capital gains tax cut will have a corresponding fall in the savings rate. Some explanations include less spending on college scholarships, human capital accumulation, and retirement accounts.

There are many reasons for the different estimation results. First is the high degree of multicollinearity between the variables in the system. While it is not surprising that DPI and wealth are highly correlated, it does cause their estimates and the standard errors to be very sensitive to the slightest change in the data. Considering that these studies differ in choosing between overlapping generations and a two-period model, in the incorporation of inflation and human capital, or differ in the inclusion of risk, bequest motives, open economy, public vs. private savings, and labor adjustments, we would expect to see the dramatically different results obtained. Another reason for the varying results is due to the value of wealth being dependent upon the interest rate. As Sims (1980) paper points out the neglect of incorporating the endogeneity of interest rates can bias results.

\subsection{Estimation}

To determine the sensitivity of savings to the after-tax interest rate return, I build on Boskin's model using an updated time period from 1966 to 2001. Using both an Ordinary Least Squares (OLS) and simultaneous equations two stage least squares approach, the following equation is estimated

where $C$ represents consumption, DPI represents disposable private income, $\Omega$ represents wealth, $R$ represents the nominal after tax rates of return for Moody's AAA bond rate adjusted for the marginal tax rate reported by $\mathrm{TAXSIM}, \pi$ represents the inflation rate, $t$ represents time, and $\beta$ represents the coefficients. Consumption and disposable private income (DPI) come from the Bureau of Economic Analysis. The St. Louis Federal Reserve Bank reports the unemployment rate, CPI, which is used as the measure of inflation, and the Moody's AAA Bond rate. The TAXSIM tax rate is reported at the www.nber.org/taxsim/ website. This proxy should move closely with that of Boskin. Results for all variables are reported in Table 1.

To estimate the elasticity of substitution, incorporating production the following is estimated:

$$
\ln \left(\frac{\mathrm{rK}}{\mathrm{y}}\right)=\partial_{1}+\beta_{1} \ln (\mathrm{r})+\beta_{2} t
$$

where $K$ is the capital stock, $r$ is the after tax return on capital, $y$ is production, and $t$ is a time trend. Results of this estimate are provided in Table 2.

While Boskin used regression with both the current and past level of the disposable private income, my results found there to be multicollinearity between these two variables. Gujarati (1995) shows that multicollinearity can cause a lack of robustness and suggests that slight modifications of the model produce drastically different 
results. This is what I observe in the estimation of interest elasticity. One solution is to delete one of the variables. Therefore, I re-estimate the regression results deleting the lag of DPI.

\subsection{Results}

Results reported in Tables 1 and 2 do not support those of Boskin's findings. Instead, the results show an interest elasticity of savings close to .2. Results in Table 2 show that the elasticity of substitution with the Ordinary Least Squares model is close to .10. This is four times lower than that found by Boskin, who showed the elasticity of substitution to be close to .44. Using the two stage least squares estimation method, the elasticity of substitution increased to close to .3 percent, but this is still much lower than that found by Boskin and Summers.

Table 2 also shows that the share of income going to capital is negative over time. This suggests that capital has been steadily decreasing since the early 1960s. Considering that labor has been increasing during this time period, this suggests that the capital to labor ratio is declining. This result is similar to that of Browne and Hellerstein (1997) who found that the capital to labor ratio has been decreasing in the United States since the 1960s. Thus, these results do not support the supply side economists who suggest that the 1980 tax cuts should increase the capital to labor ratio and productivity. Contrarily, according to this study, the exact opposite has been happening.

Results also show that disposable personal income and wealth are significant in the consumption/savings decision. As one might expect, as income and wealth increase they increase consumption. Table 1 shows that the coefficient for DPI has a .35 impact on consumption, while wealth increases consumption by .06 . As expected, unemployment has a negative but insignificant influence on consumption and savings.

Results were robust using the simultaneous equations two stage least squares method. Column two in Table 1 reports the two stage least square results. With the exception of unemployment, all other variables exhibit the same patterns as those found in the OLS regression. While the positive relationship between unemployment and the consumption/savings decision is surprising, it is very small and not statistically significant.

Regardless of the estimation technique, all results support a relatively small and stable elasticity of substitution, thus suggesting that an increase in the after-tax interest rate creates only a small and minimal effect on savings. In turn, this creates very little change in the capital to labor ratio and the productivity of labor.

\subsection{Conclusions}

There have been many conflicting estimates of the interest elasticity of substitution. Empirically, this may be due to multicollinearity, the endogeneity of interest rates, misspecifications, and different time periods. Likewise, there is no census in theory regarding how high the interest elasticity of savings should be and is today. Boskin suggests that the interest elasticity is high. As a result, he suggests that a decrease in the capital gains tax should increase savings in the long run, which will help promote productivity. In contrast, Feldstein proposes a relatively inelastic saving response to changes in the after-tax return. Thus, he supports other types of tax cuts to stimulate current consumption.

In trying to determine how tax policy can alter current and future consumption due to the savings/consumption decision, I estimate the interest elasticity of savings. Findings in this study, show a very low elasticity of savings between .1 to .3 percent. In comparison, Boskin's found that the elasticity of substitution was closer to .44 and as high as .6. Although this does not initially sound high, it suggests that the savings/consumption decision is more than twice as sensitive to changes in the after tax interest rate than results found in this study. The higher the value of the elasticity of substitution, the more switching from an capital gains tax to a consumption tax will raise the after tax rate of return and increase savings. According to Solow's growth model an increase in savings helps to increase the labor to capital ratio, increasing labors share of income. This eventually increases worker productivity and the real wage. According to Boskin, this generates a redistribution of income from capital to labor. In other words, under a capital gains tax, capital bears more of the tax burden in the long run. In contrast, results of 
this study contrast that of Boskin and Summers (1981) who found that a capital income tax cut would increase the real net rate of return causing a welfare gain in excess of $\$ 50$ billion in 1978 dollars.

Interestingly, results of this study do not support such findings. In contrast, results of this study do not suggest that a capital income tax cut generates a change in the savings/consumption decision. As a result, a capital gains tax cut would not generate much of a change in the capital to labor ratio and the productivity of labor. This may be why Browne and Hellerstein (1997) found that the capital to labor ratio has been decreasing in the United States since the 1960s. In contrast to supply side economists, President Reagan's 1981 tax cut did not appear to stimulate savings due to the relatively low elasticity of substitution. Therefore, the results of this study would argue against any further cut in capital gains taxes as a mechanism to stimulate savings and future consumption. Instead, the President and Congress may want to consider income or consumption tax cuts to increase current consumption.

\section{References}

1. Boadway, Robin, Neil Bruce and Jack Mintz (1984) "Taxation, inflation, and the effective marginal tax rate on capital in Canada" Canadian Journal of Economics, v17, n1, pp. 62-79.

2. Boskin, Michael J. (1978) "Taxation, Saving and the Rate of Interest" Journal of Political Economy, v86, n2, April, pp. 3-28.

3. Browne, Lynn Elaine and Rebecca Hellerstein (1997) "Are We Investing Too Little?" New England Economic Review, Federal Reserve Bank of Boston, Nov./Dec.

4. Evans, Owen J. (1983) "Tax Policy, the Interest Elasticity of Saving, and Capital Accumulation: Numerical Analysis of Theoretical Models" American Economic Review, v73, 00. 398-410.

5. Feldstein, Martin (1978) "The Rate of Return, Taxation and Personal Savings" The Economic Journal, v88, September, pp. 482-487.

6. Gujarati, Damodar (1995) Basic Econometrics. Third Edition. McGraw-Hill Inc. New York, NY, pp. $327-$ 333.

7. Klempere, David W. and O'Neil Cherie J. (1987) "Effects of an Inflation - Adjusted Basis on Asset Values After Capital Gains Taxes" Land Economics, v63, n4, pp. 386-395.

8. Kotlikoff J Laurence and Laurence H. Summers (1979) "Tax Incidence in a Life Cycle Model with Variable Labor Supply" Quarterly Journal of Economics, v 93, pp. 705-718.

9. Popper, Margaret (2002) "Is This Tax Cut Cutting It?” Business Week, July 22, 2002.

10. Sandmo, Agnar (1981) "The Rate of Return and Personal Savings" The Economic Journal, 91, June, pp. 536-540.

11. Seidman, Laurence S. and Stephen B. Maurer (1982) "Taxes and Capital Intensity in a Two-Class Disposable Income Growth Model” Journal of Public Economics, 19, pp. 243-259.

12. Solow, Robert M. (1956) "A Contribution to the Theory of Economic Growth" Quarterly Journal of Economics, v70, pp. 65-94.

13. Summers, Lawrence H. (1981) "Capital Taxation and Accumulation in a Life Cycle Growth Model" The American Economic Review, 71, pp. 533-544.

14. Summers, Lawrence H. (1984) "The After-Tax Rate of Return Affects Private Savings" American Economic Association Papers and Proceedings, May, pp. 249-253.

15. Uhlig, Harald and Noriyuki Yanagawa (1996) "Increasing the Capital Income Tax May Lead to Faster Growth" European Economic Review, 40, pp. 1521-1540. 


\section{Appendix}

\section{TABLE 1}

\begin{tabular}{|c|c|c|}
\hline Variable & Ordinary Least Squares Results & Two Stage Least Squares Results \\
\hline Constant & 1.377252 & 1.454126 \\
\hline Std. Errors & $(.025922)$ & 22.4454 \\
\hline t-statistics & 53.131 & .341794 \\
\hline DPI & .349595 & $(.022759)$ \\
\hline Std. Errors & $(.011957)$ & 15.018 \\
\hline t-statistics & 29.23682 & .068024 \\
\hline Wealth & .059376 & $(.026293)$ \\
\hline Std. Errors & $(.011498)$ & 2.587143 \\
\hline t-statistics & 5.164265 & .022427 \\
\hline Unemployment & -.009236 & $(.021874)$ \\
\hline Std. Errors & $(.014272)$ & 1.025286 \\
\hline t-statistics & -.647136 & -.012628 \\
\hline R & -.009766 & $(.001926)$ \\
\hline Std. Errors & $(.001567)$ & -6.555762 \\
\hline t-statistics & -6.233744 & .039287 \\
\hline Inflation & .018061 & $(.015635)$ \\
\hline Std. Errors & $(.003987)$ & 2.512806 \\
\hline t-statistics & 4.530398 & .9938 \\
\hline Adjusted R-square & .995 & \\
\hline
\end{tabular}

TABLE 2

\begin{tabular}{|l|c|c|}
\hline Variable & OLS & Two Stage Least Squares \\
\hline R & .106790 & .296115 \\
\hline Std. Errors & $(.010106)$ & $(.014175)$ \\
\hline t-statistics & 10.56730 & 20.88939 \\
\hline Time & -.006422 & -0.011232 \\
\hline Std. Errors & $(.000340)$ & $(0.000116)$ \\
\hline t-statistic & -18.87825 & -97.03391 \\
\hline Adjusted R-square & .9861122 & .983786 \\
\hline Elasticity & .10 & .296115 \\
\hline
\end{tabular}


Notes 